INTIQAD: JURNAL AGAMA DAN PENDIDIKAN ISLAM

ISSN 1979-9950 (print) || ISSN 2598-0033 (online), http://jurnal.umsu.ac.id/index.php/intiqad

DOI: https://doi.org/10.30596/intiqad.v10i2.2492

Published December 2018

\title{
Analisis Implementasi Supervisi Akademik Sebagai Upaya Peningkatan Profesionalisme Guru Agama \\ (Studi Kasus di MTsN Kabupaten Brebes dan SMP Al Irsyad Tegal)
}

\section{Abdul Majid Khon ${ }^{1 *}$, Neli Rahmaniah ${ }^{2}$}

Fakultas Ilmu Tarbiyah dan Keguruan UIN Syarif Hidayatullah Jakarta

1Email: majid@uinjkt.ac.id

${ }^{2}$ Email: neli.rahmaniah@uinjkt.ac.id

\begin{tabular}{|c|c|}
\hline Abstract & Artikel Info \\
\hline $\begin{array}{l}\text { The aims of this research are to find out; (1) the urgency of } \\
\text { academic supervision at SMP Al-Irsyad Tegal and MTsN } \\
\text { Brebes, Jawa Tengah; (2) the picture of the academic } \\
\text { supervision implementation, obstacles, and solutions; (3) the } \\
\text { positive impact of the implementation of academic } \\
\text { supervision in developing teacher of religion } \\
\text { professionalism in SMP Al-Irsyad Tegal and MTsN } \\
\text { Kabupaten Brebes, Jawa Tengah. The result showed that: } \\
\text { (1) Academic supervision is necessary to do by a supervisor, } \\
\text { in this case, the headmaster SMP Al-Irsyad Tegal and } \\
\text { MTsN Brebes, which had done supervision activity so } \\
\text { school activities can be directed to achieve the expected } \\
\text { education purposes. (2) The implementation of educators } \\
\text { supervision either at SMP Al-Irsyad Tegal or MTsN Model } \\
\text { Brebes could be reviewed in some aspects, those are the } \\
\text { purpose of supervision, the function of supervision, the } \\
\text { types and technique of the implementation of supervision } \\
\text { used. As for the steps had done, it included planning, } \\
\text { implementing, and evaluating of supervision. Meanwhile, } \\
\text { the obstacles in the implementation of supervision were a } \\
\text { complexity of the headmaster's duty as the leader, lack of } \\
\text { preparation of supervised teachers and sometimes happens } \\
\text { at the same time with other activities, such as training, } \\
\text { workshop, etc. The effort made was by coordinating with } \\
\text { senior teachers. (3) The positive impact of the } \\
\text { implementation of academic supervision is motivating } \\
\text { supervised teachers of the importance to improve } \\
\text { competence, so the quality of the learners will increase, and } \\
\text { then it shows more of a professional teacher. } \\
\text { Keywords: Implementation, Academic Supervision, } \\
\text { Professionalism of Religion Teachers }\end{array}$ & $\begin{array}{c}\text { Received: } \\
22 \text { September } 2018 \\
\text { Revised: } \\
\text { 16 October } 2018 \\
\text { Accepted: } \\
23 \text { November } 2018\end{array}$ \\
\hline Abstrak & \\
\hline
\end{tabular}


supervisi akademik di SMP Al-Irsyad Tegal dan MTsN Brebes, Jawa Tengah; (2) gambaran pelaksanaan supervisi akademik, hambatan, dan solusi; (3) dampak positif dari pelaksanaan supervisi akademik dalam pengembangan profesionalisme guru PAI di SMP Al-Irsyad Tegal dan MTsN Kabupaten Brebes, Jawa Tengah.

Hasil penelitian menunjukkan bahwa: (1) Pengawasan akademik perlu dilakukan oleh seorang supervisor, dalam hal ini, kepala sekolah SMP Al-Irsyad Tegal dan MTsN Brebes, yang telah melakukan kegiatan supervisi agar kegiatan sekolah dapat diarahkan untuk mencapai tujuan pendidikan yang diharapkan. . (2) Pelaksanaan supervisi pendidik baik di SMP Al-Irsyad Tegal maupun MTsN Model Brebes dapat dikaji dalam beberapa aspek, yaitu tujuan pengawasan, fungsi pengawasan, jenis dan teknik pelaksanaan supervisi yang digunakan. Adapun langkahlangkah yang telah dilakukan, termasuk perencanaan, pelaksanaan, dan evaluasi pengawasan. Sementara itu, hambatan dalam pelaksanaan supervisi adalah kompleksitas tugas kepala sekolah sebagai pemimpin, kurangnya persiapan guru yang diawasi dan terkadang terjadi bersamaan dengan kegiatan lain, seperti pelatihan, lokakarya, dll. Upaya yang dilakukan adalah dengan berkoordinasi dengan guru senior. (3) Dampak positif dari pelaksanaan supervisi akademik adalah memotivasi guru yang diawasi tentang pentingnya meningkatkan kompetensi, sehingga kualitas peserta didik akan meningkat, dan kemudian menunjukkan lebih banyak lagi guru yang profesional.

\section{Kata Kunci: Implementasi, Supervisi Akademik, Profesionalisme Guru Agama}

\section{A. Pendahuluan}

Pendidikan adalah sebuah sistem yang terdiri dari beberapa komponen yang saling terkait dalam usaha meraih satu tujuan. Komponen yang saling bersinergi tersebut merupakan segala aktivitas dan penunjang dalam proses pendidikan di antaranya kegiatan mengajar, melatih dan mendidik.
Kesuksesan dalam pendidikan berawal dari kesuksesa dalam kegiatan belajar dan mengajar. Tolok ukur suatu kegiatan pembelajaran berhasil ketika pseserta didik mampu menguasai serta memahami materi pembelajaran serta tujuan pembelajaran yang telah ditetapkan baik dari aspek kognitif, psikomotorik, dan psikomotorik. 


\section{INTIQAD: JURNAL AGAMA DAN PENDIDIKAN ISLAM}

ISSN 1979-9950 (print) || ISSN 2598-0033 (online), http://jurnal.umsu.ac.id/index.php/intiqad

DOI: https://doi.org/10.30596/intiqad.v10i2.2492

Published December 2018

Problematika dunia pendidikan di

Indonesia dewasa ini diantaranya adalah rendahnya lulusan pendidikan tinggi yang dapat terserap dalam dunia kerja.Sulitnya lulusan universitas lokal memperoleh pekerjaan sudah terlihat dari angka pengangguran terdidik Indonesia yang meningkat setiap tahun. Berdasarkan data Badan Pusat Statistik (BPS) pada Agustus 2014, di Indonesia ada 9,5\% (688.660 orang) dari total penganggur yang merupakan alumni perguruan tinggi. "Setelah India dan Brazil, Indonesia menempati peringkat ketiga sebagai negara dengan pertumbuhan lulusan universitas lebih dari $4 \%$ dan rata-rata surplus $1.5 \%$ per tahun. Tapi, perusahaan tetap kesulitan mendapatkan karyawan yang berpotensi tinggi," ujar Consultant Director, Willis Tower Watson Indonesia, Lilis Halim pada diskusi $A$ Taste Of L'oreal, Rabu (20/4/2016).

Sehubungan dengan kondisi mutu lulusan suatu lembaga pendidikan tersebut, menjadikan guru sebagai garda terdepan dalam proses pendidikan harus terus dikembangkan dan diupayakan untuk meningkatkan profesionalitasnya. Hal ini merupakan salah satu masalah yang menjadi tanggungjawab kepemimpinan sekolah untuk dipecahkan dan dilaksanakannya.

Sekolah maupun madrasah sebagai institusi dengan segala kapasitasnya dalam dunia pendidikan, memiliki beberapa perlengkapan dalam merealisasikan kapasitasnya tersebut melalui kegiatan pengelolaan pendidikan yang baik, sementara kepala sekolah sebagai daya pengggerak organisasi dalam kegiataan pengelolaan untuk mengarahkan seluruh pendidik agar melaksanakan kegiatan pembelajaran menjadi lebih bermutu.

Dalam usaha mengembangkan kualitas sumber daya pendidikan, guru adalah fokus dan sasaran utama yang menjadi perhatian dalam pengembangan kompetensi. Pengembangan kualitas guru dilaksanakan melalui kegiatan prajabatan dan program dalam jabatan. Tidak semua guru yang dbina pada lembaga pendidikan, terbina dengan maksimal dan berkualifikasi. Kompetensi pendidik harus secara kontinu harus terus dikembangkan agar para pendidik mampu menjalankan tugasnya dengan secara profesional. Hal ini didorong juga dengan perubahan zaman dan teknologi yang menuntut pendidik untuk terus menerus berinovasi. 


\section{INTIQAD: JURNAL AGAMA DAN PENDIDIKAN ISLAM}

ISSN 1979-9950 (print) || ISSN 2598-0033 (online), http://jurnal.umsu.ac.id/index.php/intiqad

DOI: https://doi.org/10.30596/intiqad.v10i2.2492

Published December 2018

Usaha peningkatan mutu dan profesionalitas guru sangat berhubungan erat dengan efektivitas kegiatan supervisi yang dilakukan supervisor dalam hal ini kepala sekolah. Kegiatan supervisi ini diharapkan memicu guru untuk mengembangkan empat kompetensi yang harus dimiliki oleh guru.

Judul yang diangkat dalam penelitian ini adalah "Analisis Implementasi Supervisi Akademik Sebagai Upaya Peningkatan Profesionalisme Guru (Studi Kasus di MTs Negeri Kabupaten Brebes Dan SMP Al Irsyad Tegal)”. Subyek penelitian yang dipilih adalah di SMP Al-Irsyad Kab. Tegal dan MTs Negeri Model Kab. Brebes Jawa Tengah. Dua sekolah yang berbeda, yakni sekolah yang berbasis umum yaitu SMP dan sekolah yang berbasis agama yakni MTsNegeri Brebes. Dua sekolah tersebut juga berbeda status yakni antara madrasah negeri dan sekolah swasta maka dapat menghasilkan data yang variatif, homogen, dan luas. Dengan demikian data hasil temuan bisa lebih banyak terjaring.Sekolah SMP al-Irsyad berada dibawah naungan Yayasan Perguruan Al-Irsyad Tegal, dengan status akreditasi A dan memperoleh klasifikasi sebagai sekolah potensial Saat ini. Demikian juga MTsNegeri Brebes sebagai madrasah model yang terakreditasi A oleh Badan Akreditasi Nasional.

Diharapkan dengan dilakukannya supervisi akademik upaya pemerintah untuk meningkatkan kualitas pendidik di Indonesia dapat terwujud sehingga proses belajar mengajar dapat terwujud secara efektif dan efisien. Supervisi akademik perlu dilakukan secara konsisten supaya tujuan tersebut dapat terpenuhi.

\section{B. Metode Penelitian}

Metode penelitian yang digunakan dalam penelitian ini yaitu kualitatif. Dalam pengumpulan data, teknik yang digunakan yaitu wawancara kepada kepala sekolah, guru-guru serta pengawas yang terkait di SMP al-Isyad Tegal dan MTs Negeri Brebes. Selain itu teknik yang dilakukan juga dengan observasi, dokumentasi serta penyebaran kuesioner dan angket.

Untuk teknik analisis data yang digunakan yaitu analisis deskriptif kualitatif yaitu dengan melakukan kegiatan mereduksi data, menyajikan 


\section{INTIQAD: JURNAL AGAMA DAN PENDIDIKAN ISLAM}

ISSN 1979-9950 (print) || ISSN 2598-0033 (online), http://jurnal.umsu.ac.id/index.php/intiqad

DOI: https://doi.org/10.30596/intiqad.v10i2.2492

Published December 2018

data serta diakhiri dengan membuat kesimpulan.

\section{Supervisi Akademik}

Pengertian supervisi yang dikutip oleh Piet A. Sahertian adalah kegiatan yang dalam rangka untuk meningkatkan kualitas pembelajaran yang terdiri dari kegiatan stimulasisasi, seleksi perkembangan jabatan pendidik serta mengubah tujuan pendidikan, materi, metode serta evaluasi pembelajaran. Subjek yang berperan dalam usaha menstimulasi pendidik agar mengembangkan proses pembelajaran yang lebih berkualitas disebut supervisor. Semua guru tetap pada posisinya sebagai guru, namun di lain kesempatan ketika seorang guru mampu berkontribusi dengan memberikan solusi dari problema pembelajaran dalam usaha merealisasikan tujuan pendidikan, maka pada saat itu posisi seorang guru juga merangkap sebagai supervisor. ${ }^{1}$

Ngalim Purwanto menjelaskan bahwa supervisi merupakan suatu kegiatan pembinaan yang terencana untuk memfasilitasi pendidik dan tenaga kependidikan untuk melaksanakan

\footnotetext{
${ }^{1}$ Piet. A. Sahertian dan Frans Mataheru, Konsep dasar dan teknik: Supervisi pendidikan (dalam rangka pengembangan sumber daya manusia), (Jakarta: Rineka Cipta, 2000), h.17
}

pekerjaaan secara maksimal. Supervisi juga didefinisikan sebagai upaya bantuan yang dilakukan oleh kepala sekolah seperti motivasi, pelatihan bimbingan serta kesempatan kepada guru-guru dalam mengembangkan kompetensi dan keterampilan dalam mengajar serta melakukan inovasi-inovasi dalam pendidikan dan pengajaran, serta bekal pengetahuan dalam memilih media, metode serta sistem evaluasi pembelajaran. $^{2}$

Beranjak dari penjelasan di atas dapat disimpulkan bahwa supervisi merupakan suatu usaha pembinaan bimbingan yang dilaksanakan oleh pimpinan sekolah kepada pendidikan dan tenaga kependidikan. Supervisor bertindak sebagai motivator, stimulator, serta tempat berkonsultasi bagi para pendidik dalam memperbaiki proses belajar mengajar dan menciptakan iklm pembelajaran yang baik dalam peningkatan saran maupun prosess pembelajaran.

Kepala sekolah sebagai leader berperan dalam peningkatan kompetensi profesionalitas guru yang berorientasi pada peningkatan performa guru yang

\footnotetext{
${ }^{2}$ Ngalim Purwanto, Administrasi dan Supervisi Pendidikan, (Bandung: Remaja Rosdakarya, 2009), h.76
} 


\section{INTIQAD: JURNAL AGAMA DAN PENDIDIKAN ISLAM}

ISSN 1979-9950 (print) || ISSN 2598-0033 (online), http://jurnal.umsu.ac.id/index.php/intiqad

DOI: https://doi.org/10.30596/intiqad.v10i2.2492

Published December 2018

dilakukan secara kontinu sehingga berlaku sehingga dapat

bermuara pada pencapaian target yang diharapkan. Selain itu, kegiatan pembinaan harus mengarah pada peningkatan tugas pokok dan fungsi dari guru di setiap institusi pendidikan. Intensitas kegiatan pelatihan dan pembinaan kompetensi guru akan berpengaruh pada peningkatan profesionalitas guru dalam mengemban tugas mendidik.

Burhanuddin menjelaskan bahwa tujuan supervisi pendidikan adalah membantu guru dalam melakukan inovasi-inovasi dalam pembelajaran sehingga mengarah pada perbaikan kualitas pembelajaran yang dengan kegiatan pelatihan dan pembinaan. Secara lebih mendetail tujuan supervisi di antaranya: ${ }^{3}$

1. Meningkatkan efektivitas dan efisiensi proses belajar.

2. Melakukan pengendalian dalam pelaksanaan pendidikan di sekolah sesuai peraturan yang ditetapkan.

3. Memberikan arah agar seluruh aktivitas yang di sekolah berjalan sesuai dengan ketetapan yang

\footnotetext{
${ }^{3}$ Burhanudin, Manajemen Sekolah Berbasis Perubahan Kurikulum, Diambil pada tanggal $05 \quad$ April 2010 dari http://www.depdiknas.go.id, 2002, h.14
}

berlangsung dan menghasilkan hasil yang maksimal.

4. Memberikan penilaian terhadap pelaksanaan di sekolah.

5. Memberikan layanan dan solusi terhadap segala problem yang dihadapi sekolah sehingga mampu berkembang dengan memperbaiki kesalahan dan kekurangan yang pernah dilaksanakan.

Sahertian mengungkapkan bahwa fungsi penting dari kegiatan supervisi adalah mengevaluasi serta melakukan perbaikan-perbaikan terhadap hal-hal yang dapat mengganggu keberhasilan dalam proses pembelajaran. Lebih lanjut Sahertian menguraikan terdapat delapan fungsi dari supervisi, di antaranya: ${ }^{4}$

1. Untuk melakukan koordinasi segala aktivitas sekolah

2. Memaksimalkan kinerja kepala sekolah

3. Menambah wawasan serta pengalaman guru dalam mendidik

4. Menstimulus para guru untuk melakukan inovasi pembelajaran

5. Melakukan evaluasi serta penilaian secara kontinu

${ }^{4}$ Piet, Sahertian dan Frans Mataheru, Konsep, h.21. 


\section{INTIQAD: JURNAL AGAMA DAN PENDIDIKAN ISLAM}

ISSN 1979-9950 (print) || ISSN 2598-0033 (online), http://jurnal.umsu.ac.id/index.php/intiqad

DOI: https://doi.org/10.30596/intiqad.v10i2.2492

Published December 2018

6. Menganalisis iklim belajar

7. Membekali tenaga kependidikan dengan pengetahuan dan keterampilan.

8. Membantu guru dalam meningkatkan kualitas pembelajaran serta mengintegrasikan tujuan pendidikan.

Berjalan dari fungsi-fungsi supervisi di atas, maka disimpulkan bahwa pelaksanaan supervisi harus dilakukan dilakukan secara kontinu dengan mengerahkan segala potensi yang terdapat di sekolah termasuk di dalamnya usaha guru dalam meningkatkan kompetensinya sebagai seorang pendidik serta secara simultan melakukan inovasi-inovasi dalam rangka memperbaiki kegiatan di sekolah. Hal ini juga dilakukan dengan kegiataan kordinasi secara teratur agar mendukung terealisasinay seluruh program sekolah.

Dengan demikian perlu dikoordinasikan secara terarah agar benar-benar dapat mendukung kelancaran program secara keseluruhan.

\section{Profesionalisme Guru}

Kata "guru" memiliki makna pendidik profesional dengan tugas penting yaitu mengajar, mendidik, melatih, membimbing, menilai serta melakukan evaluasi terhadap peserta didik melalui jalur pendidikan formal. Ace Suryadi berpandangan bahwa guru yang bermutu adalah guru yang memiliki kompetensi profesional yang baik dengan segala keahlian sebagai seorang pendidik. ${ }^{5}$

Pengembangan mutu guru merupakan hal yang sangat penting dikarenakan subtansi kajian dan konteks pembelajaran selalu berkembang sesuai dengan dimensi ruang dan waktu, sehingga guru dituntut untuk selalu meningkatkan kompetensi yang dimilikinya. ${ }^{6}$ Selain itu, perlunya dilakukan pembinaan terhadap guru didasarkan pada karakteristik tugas yang terus berkembang dengan perkembangan Ipteks, disamping reformasi internal pendidikan itu sendiri.

\section{E. Hasil Penelitian}

\section{Implementasi Supervisi}

Implementasi supervisi kepala sekolah yang melibatkan guru senior, guru yang dinilai, serta siswa diharapkan dapat meningkatkan performa dan

\footnotetext{
5 Ace Suryadi, Menyoal Mutu Profesi Guru, Kompas: Jakarta, 9 Maret 2001.

6 Udin S. Saud dan Cicih Sutarsih, Pengembangan Profesi Guru SD, (Bandung: UPI Press, 2007), h. 101
} 


\section{INTIQAD: JURNAL AGAMA DAN PENDIDIKAN ISLAM}

ISSN 1979-9950 (print) || ISSN 2598-0033 (online), http://jurnal.umsu.ac.id/index.php/intiqad

DOI: https://doi.org/10.30596/intiqad.v10i2.2492

Published December 2018

profesionalitas guru serta dapat mengembangkan proses pembelajaran baik di SMP Al-Irsyad Tegal maupun di MTsNegeri Model Brebes. Kegiatan supervisi tersebut dilatarbelakangi oleh Peraturan Menteri Pendidikan Nasional No.13 Tahun 2007 mengenai kompetensi-kompetensi yang wajib dimiliki oleh kepala sekolah termasuk kompetensi supervisi.

Supervisi dilakukan secara rutin setiap semester sehingga menjadi tradisi untuk mempersiapkan segala sesuatunya yang diperlukan dalam pelaksanaannya. Supervisi akademik menurut Kepala Madrasah (Kamad) MTsN Brebes adalah proses pembinaan yang berupa bimbingan ke arah perbaikan situasi KBM dalam rangka perbaikan dan peningkatan mutu kegiatan belajar mengajar. Di sini supervisi diartikan bimbingan dan perbaikan proses pembelajaran bukan berarti mencari-cari kesalahan guru dan bukan mengajari guru atau menggurui guru karena mereka sudah menjadi guru. Dengan arti yang sederhana ini memberi gambaran supervisi dapat berjalan dengan damai dan baik karena supervisi merupakan kebutuhan bersama yang harus dilaksanakan demi kemajuan sekolah.
Supervisi dalam implementasinya tidak dilaksanakan oleh pimpinan sendiri akan tetapi oleh tim karena mengingat banyaknya jumlah guru, kayawan dan murid (guru berjumlah 88 orang pegawai/karyawan berjumlah 24 orang dan murid berjumlah 1.536). Tim supervisi terdiri dari kamad atau kasek, wakasek atau wakamad bidang kurikulum bersama ketua MGMP dan guru senior untuk melakukan supervisi terhadap para guru. Demikian juga kepala sekolah atau kepala madrasah dibantu oleh guru senior yang merupakan bagian dari tim supervisi.

Implementasi supervisi di MTsN meliputi 4 langkah yaitu perencanaan, pelaksanan, evaluasi dan tindak lanjut.

\section{Perencanaan}

Segala suatu memerlukan perencanaan, dan sesuatu yang dilakukan melalui perencanaan tentunya hasilnya akan lebih baik dari pada tidak direncanakan. Kepala sekolah merencanakan dan gurupun juga merencanakan. Perencanaan supervisi dilakukan oleh Kamad bersama wakilnya dan Ketua MGMP untuk menyusun jadwal supervisi dan penyediaan form untuk membantu guru 


\section{INTIQAD: JURNAL AGAMA DAN PENDIDIKAN ISLAM}

ISSN 1979-9950 (print) || ISSN 2598-0033 (online), http://jurnal.umsu.ac.id/index.php/intiqad

DOI: https://doi.org/10.30596/intiqad.v10i2.2492

Published December 2018

dalam mempersiapkan proses pembelajarannya.

a. Sosialisasi melalui rapat guru

Sebelum disupervisi guru-guru diberitahukan terlebih dahulu tentang tugas dan kewajibannya dalam proses pembelajaran KBM melalui sosialisasi dalam rapat awal semester termasuk jadwal pembelajaran yang akan diampu atau tugas yang diberikan dalam satu semester. Sosialisasi ini dimaksudkan agar guru lebih siap untuk melaksanakan tugasnya dan siap disupervisi.

b. Persiapan perangkat pembelajaran /administrasi

Persiapan guru sebelum disupevisi dilengkapi baik menyangkut media maupun administrasi.Kepala madrasah menyediakan pembagian tugas mengajar sesuai dengan bidang keahliannya. Kepala madrasah juga menyiapkan adminstrasi penunjang $\mathrm{KBM}$, termasuk absensi murid, jurnal kegiatan KBM dan nilai. Kemudian guru mempersiapkan perangkat pembelajaran antara lain sebagai berikut:

1) Kurikulum

2) Silabus mata pelajaran yang diampu

3) RPP Rencana Pelaksanaan Pembelajaran)
4) Penilaian atau evaluasi pembelajaran baik sebelum mengajar (pretest) maupun sesudahpembelajaran (posttest), PTS (Penliaian Tengah semester) PAS (Penilaian Akhir Semester) dan PAT (Penilaian Ahir Tahun Pelajaran)

5) Prota (Program Tahunan )

6) Proter (Program Semester) dan

7) $\mathrm{KKM}$ (Kriteria Ketuntasan Minimal)

Menurut sebagian guru bahwa pada umumnya guru sudah siap dan telah mempersiapkan perangkat pembelajaran yang sudah rutin terjadwal setiap tahun bahkan sebelum tahun ajaran guru dengan sendirinya telah mempersiapkannya. Perangkat perlengkapan di atas yang harus dipersiapkan oleh guru pada tahap perencanaan ini dengan mendapat bimbingan dan bantuan dari guru inti yang ditugaskan. Format dan bahanbahannya disediakan oeleh tim supervisor.

\section{Pelaksanaan Supervisi}

Supervisi dilaksanakan setelah sosialisasi perencanaan dan persiapan terlebih dahulu. Supervisi dilakukan adakalanya secara langsung dan 


\section{INTIQAD: JURNAL AGAMA DAN PENDIDIKAN ISLAM}

ISSN 1979-9950 (print) || ISSN 2598-0033 (online), http://jurnal.umsu.ac.id/index.php/intiqad

DOI: https://doi.org/10.30596/intiqad.v10i2.2492

Published December 2018

adakalanya tidak langsung. Supervisi secara langsung dilakukan pada saat di kelas maupun di luar kelas sebelum dan sesudah melaksanakan proses pembelajaran. Supervisi langsung dengan cara memonitor proses pembelajaran yang dilakukan seorang guru dalam kelas melalui kamera, CCTV sebagaimana yang dipasang di kelaskelas unggulan di MTsN Brebes, dan lain-lain. Supervisi langsung ini dilaksanakan secara berkala setiap awal semester bahkan setiap hari sebagai pembinaan dengan cara ceklis KBM dengan target kurikulum. Sedang supervisi tidak langsung atau secara kolaboratif cukup dengan memperhatikan administrasi pembelajaran yang dilakukan oleh seorang guru, profil seorang guru, output, dan lain-lain. Supervisi kolaboratif sebagai pendukung atau penguat supervsi langsung.

Langkah-langkah supervisi yang diambil oleh Kepala Sekolah atau Kepala Madrasah di antaranya:

a. Kepala Madrasah atau Kepala Sekolah menugaskan beberapa guru inti sebagai Tim supervisi yang mengkoordinir kelompok guru bidang studi yang sama b. Kepala madrasah menugaskan semua guru aktif mengikuti kegiatan MGMP untuk membahas materimateri pembeljaran, kisi-kisi, soal ujian, penyajian pembelajaran aktif sebagaimana hari ini guru IPS dan muridnya belajar alam di Batang Flora Fauna.

c. Pelaksanaan supervisi langsung diberikan kepala madrasah atau timnya kepada guru secara individual dan pembinaannya face to face atau secara kolektif.

Pra observasi Kepala Madrasah atau Sekolah tentunya memeriksa perlengkapan perangkat pembelajaran meliputi silabus, RPP, buku teks mata pelajaran, sumber pembelajaran dan lainlain. Saat observasi Kepala Sekolah atau tim supervisi duduk di posisi belakang kelas serta melakukan observasi terhadap pelaksanaan KBM yang dilaksanakan oleh seorang guru termasuk active learning-nya atau cara mengaktifkan siswa dalam pembelajaran. Kepala Sekolah atau tim supervisi memperhatikan guu dalam proses pembelajaran atau KBM yang meliputi:

a. Pendahuluan, bagaimana guru menyiapkaan anak didiknya secara 


\section{INTIQAD: JURNAL AGAMA DAN PENDIDIKAN ISLAM}

ISSN 1979-9950 (print) || ISSN 2598-0033 (online), http://jurnal.umsu.ac.id/index.php/intiqad

DOI: https://doi.org/10.30596/intiqad.v10i2.2492

Published December 2018

psikis dan fisik, bagaimana guru mengajukan pertanyaan pada pretest dan bagaimana guru menyampaikan tujuan pembelajaran yang ingin dicapai

b. Kegiatan Inti

Pada kegiata inti ini yang diperhatikan adalah bagaimana guru melaksanakan proses pembelajaran dengan proses $5 \mathrm{M}$ yaitu mengamati (observing), menanya (questioning), menalar (assosiating), mencoba (experimenting), dan membentuk jejaring (networking).

c. Kegiatan penutup

Bagaimana seorang guru membuat ragkuman pembelajaran bersama murid-muridnya dan mengajukan pertanyaan posttest.

\section{Evaluasi}

Tim supervisi melakukan pengawasan proses eksplorasi, pembelajaran, melakukan monitoring, supervisi dan evaluasi KBM dan kinerja guru serta tindak lanjut dari penilaian tersebut. Ada beberap cara dalam evaluasi kinerja guru yang dilakukan oleh tim supervisi, yaitu sebagai berikut:

a. Tim supervsi memberikan penilaian kinerja seorang guru baik pada perencanaan (RPP) maupun pelaksanaan pembelajaran yang dilakukan oleh seorang guru, mulai dari pengantar, kegiatan inti dan penutup. Aspek-aspek penilian sudah dituangkan pada Instrumen penilaian.

b. Kamad/Kasek atau tim supervisi mencatat kekurangan dan kelebihan pada instrumen supervisi baik dari perangkat pembelajaran maupun pelaksanaan KBM

c. Catatan itu dituangkan pada instrumen penilaian baik penilaian terhadap RPP maupun instrumen penilaian pelaksanaan pembelajaran, untuk pembinaan dan perbaikan berikutnya.

d. Setelah selesai disupervisi guru yang bersangkutan boleh melihat instrumen hasil penilaian dan catatan supervisor tersebut untuk diterima kalau memang sesuai dengan kenyataan yang sesungguhnya atau boleh keberatan jika tidak sesuai dengan kenyataan yang sesungguhnya.

e. Guru berhak konfirmasi atau koreksi jika ada yang tidak sesuai dengan yang sesungguhnya sedangkan tim supervisi membuka pintu bagi guru 


\section{INTIQAD: JURNAL AGAMA DAN PENDIDIKAN ISLAM}

ISSN 1979-9950 (print) || ISSN 2598-0033 (online), http://jurnal.umsu.ac.id/index.php/intiqad

DOI: https://doi.org/10.30596/intiqad.v10i2.2492

Published December 2018

yang ingin konfirmasi atau atas

keberatannya.

f. Kemudian guru diminta tanda tangan hasil supervise

g. Evaluasi juga disampaikan secara umum pada saat rapat bulanan yaitu setiap tanggal 17 setelah upacara bendera

h. Penilaian Kamad juga dilakukan terhadap guru dalam hal kaitannya dengan kinerja dan sikapnya dalam bentuk DP3 (Daftar Penlaian Pelaksanaan Pekerjaan).

Dalam evaluasi tim supervisi juga melakukan penilaian hasil pembelajaran secara konsisten, sistematis dan terprogram dengan menggunakan test maupun non test dalam bentuk tertulis atau lisan (pengamatan kerja, pengukuran sikap, penilaian hasil karya dan tugas). Instrumen yang dijadikan penilaian adalah hasil PTS (Penilaian Tengah Semester), PAS (Penilaian Akhir Semester) dan PAT (Peniaian Akhir Tahun).

Penilaian Kamad/Kasek adakalanya secara lisan dan adakalanya tertulis, feedback lewat isiaan secara klasikal dengan tulisan secara personal. Secara tertulis Kamad memberikan penilaian kinerja guru, secara umum lisan dan secara khusus tertulis. Penyampaian secara umum disampaikan dalam rapat dewan guru yang diadakan setiap tanggal 17 setiap bulan maupun persemesteran. Penilaian khusus secara lisan dan trtulis melalui DP3 PKG, teguran, dan penilaian SKP/PKG untuk kelancaran KBM dengan baik.

\section{Tindak lanjut}

Hasil evaluasi supervisi di atas dijadikan pijakan untuk perbaikan pembelajaran, baik berkaitan dengan penguasaan materi, strategi pembelajaran, pendekata atau media yang digunakan da lain-lain. Beberapa langkah dalam perbaikan yaitu sebagai berikut:

a. Pengadaan media Lcd setiap kelas fullday atau Lcd gendong tenteng di kelas-kelas reguler

Semua kelas fullday telah terpasang Led dan wifi untuk melengkapi media pembelajaran yang diperlukan agar proses pembelajaran bisa berjalan sebagaimana mestinya dan pembelajaran siswa akan lebih aktif karena proses pembelajarannya menggunakan media berbasis IT. Sedangkan di kelas reguler mengunakan Lcd gendong atau tenteng yang berpindah-pindah diambil dari ruang 


\section{INTIQAD: JURNAL AGAMA DAN PENDIDIKAN ISLAM}

ISSN 1979-9950 (print) || ISSN 2598-0033 (online), http://jurnal.umsu.ac.id/index.php/intiqad

DOI: https://doi.org/10.30596/intiqad.v10i2.2492

Published December 2018

kantor dibawa masuk kelas sesuai dengan kelas yang membutuhkan kelas. Ini dimaksudkan pelayanan yang baik sekalipun keterbatasan media tetapi program madrasah akan selalu berusaha melengkapi segala kekurangannya.

b. Perbaikan sarana prasarana yang nyaman (AC/ kipas angin)

Semua kelas fullday terpasang AC sedang kelas reguler menggunakan AC. Hal ini bukan membeda-bedakan kelas antara kelas ekonomi dan kelas eksklusif, tetapi pembiayaannya sesuai dengan pilihan dan kemampuan siswa.

c. Pembinaan strategi pembelajaran

Pembinaan guru selalu ditingkatkan dan di-update untuk meningkatkan skill guru dalam melaksanakan proses pembelajarn yang aktif dan enovatif. Semua guru tetap telah lulus mengikuti pelatihan dan pendidikan guru profesional (PLPG) dan aktf mengikuti pelatihan, seminar dan diskusibaik yang diselenggarakan oleh madrasah bekerja sama dengan instansi lain maupun yang diselenggarakan oleh instansi lain dalam rangka mendukung kompetensi yang diinginkan. Pembinaan juga selalu diadakan melaui rapat bulanan setiap tanggal tujuh belas. d. Pembinaan penguasaan dan pendalaman materi

Pembinaan penguasaan materi dan pendalaman materi dilaksanakan melalui workshop-workshop ataupun kajiankajian yang dapat meningkatkan pendalaman dan wawasan bidang keilmuan para guru. Kajian banyak diselenggarakan baik oleh madrasah maupun oleh pesantren yang ada di sekitar madrasah. Guru juga diberi pengetahuan tentang KKM dan aplikasi penilaian baik dikemas dalam sarana workshop maupun aktif mengikuti kegiatan-kegiatan MGMP.

e. Mengikutsertakan diklat sesuai dengan bidangnya

Kepala madrasah merespon dan mendorong para guru mengikuti diklatdiklat untuk meningkatkan kompetensi bidang keahlian guru dengan mengadakan kerjasama dengan kemenag kabupaten, provinsi dan pusat. Setiap tahun selalu ada undangan guru mengikuti diklat terutama yang diselenggarakan pusdiklat tenaga teknis pendidikan dan kagamaan Kemenag RI dari angkatan ke angkatan mencakup semua bidang studi keahlian guru 


\section{INTIQAD: JURNAL AGAMA DAN PENDIDIKAN ISLAM}

ISSN 1979-9950 (print) || ISSN 2598-0033 (online), http://jurnal.umsu.ac.id/index.php/intiqad

DOI: https://doi.org/10.30596/intiqad.v10i2.2492

Published December 2018

Semua kebijakan di atas sebagai tindak lanjut dari evauasi kekurangan madrasah dan kekurangan guru dalam melaksanakan pembelajaran sehingga guru dan siswa dapat belajar dengan nyaman dan kondusif, guru dan siswa dapat mengakses sumber-sumber pembelajaran di skitarnya dengan lancar.

Pelaksanaan supervisi yang melibatkan seluruh komponen pendidik baik di SMP Al-Irsyad Tegal maupun di MTsNegeri Model Brebes tersebut dapat ditinjau dari beberapa hal, yaitu; tujuan supervisi, fungsi supervisi, tipe serta teknik pelaksanaan supervisi yang digunakan.

a. Tujuan supervisi

Kegiatan supervisi pada intinya adalah memberikan layanan kepada guru-guru apabila mereka mempunyai beberapa permasalahan dalam pengembangan pembelajaran. Tujuan supervisi yaitu memberikan layanan bimbingan dalam meningkatkan kualitas belajar peserta didik. Akan tetapi, tidak hanya untuk memperbaiki performa guru dalam mengajar, namun juga mengembangkan potensi dan serta profesionalitas guru. Sesuai dengan pendapat yang dikemukakan oleh Olivia
(1984) bahwa sasaran atau tujuan supervisi pendidikan adalah:

1) Mengembangkan kurikulum pembelajaran.

2) Meningkatkan kualitas pembelajaran.

3) Meningkatkan kompetensi seluruh tenaga kependidikan di sekolah. ${ }^{7}$

Tujuan supervisi dalam kaitan supervisi yang dilakukan di SMP AlIrsyad memiliki tujuan yaitu mendapatkan data tentang kondisi dan problem yang sering dihadapi oleh pendidik, tenaga kependidikan dalam penyelenggaran kegiatan belajar dan mengajar di sekolah, memberi saran kepada pendidik dan tenaga kependidikan terhadap kinerja yang sudah ditampilkan.

Selain itu, supervisi bertujuan sebagai usaha memperbaiki dan mengembangkan kegiatan belajar mengajar secara keseluruhan. Hal ini menunjukkan bahwa tujuan kegiatan supervisi tidak hanya memperbaiki kualitas pembelajaran yang dilakukan guru, namun juga mengembangkan kompetensi profesi guru dalam arti yang lebih luas. Maka adanya supervisi bagi

${ }^{7}$ Ibid, h.19 


\section{INTIQAD: JURNAL AGAMA DAN PENDIDIKAN ISLAM}

ISSN 1979-9950 (print) || ISSN 2598-0033 (online), http://jurnal.umsu.ac.id/index.php/intiqad

DOI: https://doi.org/10.30596/intiqad.v10i2.2492

Published December 2018

pembinaan profesi guru menjadi hal yang sangat urgen bagi sekolah.

Kegiatan supervisi pada intinya adalah memberikan layanan kepada guru-guru apabila mereka mempunyai beberapa permasalahan dalam pengembangan pembelajaran. Tujuan supervisi yaitu memberikan bimbingan untuk meningkatkan kualitas pembelajaran peserta didik. Akan tetapi, tidak hanya untuk memperbaiki kemampuan mengajar, melainkan juga untuk mengembangkan potensi dan kualitas guru serta peningkatan profesionalisme kerjanya.

a. Fungsi supervisi

Fungsi dari supervisi itu sendiri adalah untuk memelihara program pembelajaran dengan sebaikbaiknya.Fungsi supervisi bukan hanya sekedar mengembalikan atau mengontrol kegiatan yang telah dilaksanakan apakah sesuai dengan program yang telah dibuat sebelumnya.Atau secara singkat bahwa fungsi utama dari adanya kegiatan supervisi adalah ditujukan pada perbaikan pengajaran. Menurut Swearingen (1961) menyatakan fungsifungsi supervisi sebagai berikut:

1) Untuk melakukan koordinasi segala aktivitas sekolah
2) Memaksimalkan kinerja kepala sekolah

3) Menambah wawasan serta pengalaman guru dalam mendidik

4) Menstimulus para guru untuk melakukan inovasi pembelajaran

5) Melakukan evaluasi serta penilaian secara kontinu

6) Menganalisis iklim belajar

7) Membekali tenaga kependidikan dengan pengetahuan dan keterampilan.

8) Membantu guru dalam meningkatkan kualitas pembelajaran serta mengintegrasikan tujuan pendidikan. ${ }^{8}$

Jika fungsi-fungsi tersebut berhasil dikuasai dan dijalankan dengan sebaikbaiknya oleh pemimpin pendidikan termasuk kepala sekolah terhadap anggotanya yaitu para guru dan staff di lingkungan sekolah, maka kelancaran jalannya kegiatan dalam mencapai tujuan pendidikan akan lebih mudah dicapai dan terjamin.

Fungsi dari supervisi pendidikan yang dilakukan oleh kepala sekolah serta guru senior di SMP Al-Irsyad yaitu sebagai sumber informasi bagi pengembangan profesionalisme guru,

${ }^{8}$ Ibid, h.21 


\section{INTIQAD: JURNAL AGAMA DAN PENDIDIKAN ISLAM}

ISSN 1979-9950 (print) || ISSN 2598-0033 (online), http://jurnal.umsu.ac.id/index.php/intiqad

DOI: https://doi.org/10.30596/intiqad.v10i2.2492

Published December 2018

dengan meningkatkan kompetensikompetensi yang seharusnya. Semua fungsi-fungsi dari kegiatan tersebut tetap mengarah kepada satu tujuan yaitu meningkatkan mutu dan kualitas lulusan peserta didik, yang pada akhirnya meningkatkan mutu pendidikan nasional. Oleh karena itu, dalam pelaksanaan supervisi pendidikan, kepala sekolah beserta guru senior supervisor sebisa mungkin harus berdasarkan pedoman yang ada, sehinngga fungsi-fungsi dari supervisi tersebut dapat dicapai dengan baik.

Fungsi dari supervisi itu sendiri adalah untuk memelihara program pembelajaran dengan sebaikbaiknya.Fungsi supervisi bukan hanya sekedar mengembalikan atau mengontrol kegiatan yang telah dilaksanakan apakah sesuai dengan program yang telah dibuat sebelumnya.Atau secara singkat bahwa fungsi utama dari adanya kegiatan supervisi adalah ditujukan pada perbaikan pengajaran.

\section{b. Teknik supervisi}

Kepala sekolah sebagai leader sekolah melaksanakan kegiatan supervisi dengan menggunakan teknik supervisi. Oleh karena itu, setiap kepala sekolah dituntut untuk menguasai keahlian tentang teknik-teknik supervisi. Purwanto menjelaskan bahwa supervisi dapat dilaksanakan dengan berbagai metode agar tujuan yang ditetapkan dapat terealisasi.

Oleh karena itu, setiap kepala sekolah atau supervisor harus memiliki keterampilan teknikal berupa kemampuan menerapkan teknik-teknik supervisi yang tepat. Menurut Ngalim Purwanto, supervisi dapat dilakukan dengan berbagai cara, dengan tujuan agar apa yang diharapkan bersama dapat menjadi kenyataan.

Ada dua teknik supervisi yang dapat digunakan yaitu teknik perseorangan dan teknik kelompok. ${ }^{9}$ Kepala sekolah dan guru senior supervisor di SMP Al_Irsyad Tegal dan di MTs Model Brebes melakukan supervisi juga menerapkan teknik supervisi secara individual dan kelompok dengan mempertimbangkan kondisi dan situasi yang ada. Teknik individual dilaksanakan dengan melakukan kunjungan serta pengamatan di kelas, sementara teknik kelompok yaitu dengan mengklasifikasikan guru yang memiliki problem yang sama untuk

9 Ngalim Purwanto, Administrasi dan Supervisi Pendidikan, h.120 


\section{INTIQAD: JURNAL AGAMA DAN PENDIDIKAN ISLAM}

ISSN 1979-9950 (print) || ISSN 2598-0033 (online), http://jurnal.umsu.ac.id/index.php/intiqad

DOI: https://doi.org/10.30596/intiqad.v10i2.2492

Published December 2018

dilakukan tindakan berikutnya oleh supervisor. Teknik supervisi kelompok dikemas dengan beragam cara, yaitu dengan rapat rutin dengan para guru, untuk membahas hal yang terkait kegiatan pembelajaran di sekolah, workshop, lokakarya, diklat atau bahkan diskusi.

c. Tipe supervisi

Sehubungan dengan kegiatan supervisi pendidikan yang dilakukan oleh kepala sekolah sudah jelas bahwa tujuan dari kegiatan supervisi kepala sekolah adalah untuk membantu guruguru dalam mengembangkan potensi dan kompetensi yang mereka miliki dengan sebaik-baiknya. Untuk mengembangkan potensi tersebut, pelaksanaan supervisi tidak lepas dari adanya tipe-tipe supervisi. Menurut Brigss dan Soewarji mengemukakan bahwa ada empat tipe, yaitu; supervisi yang bersifat korektif, ada juga yang bersifat preventif, supervisi yang bersifat konstruktif, dan supervisi yang bersifat kreatif. ${ }^{10}$

Pelaksanaan supervisi pendidikan yang dilakukan oleh kepala sekolah yang dilakukan di SMP Al-Irsyad Tegal dan MTsNegeri Model Brebes juga tidak Konsep, h. 155

10 Piet, Sahertian dan Frans Mataheru,

Copyright (C 2018. Intiqad: Jurnal Agama dan Pendidikan Islam. This is an open acces article under the CC-BY-SA lisence (https://creativecommons.org/licenses/by-sa/4.0/). lepas dari penggunaan tipe-tipe tersebut. Adapun tipe supervisi yang diterapkan di SMP Al-Irsyad Tegal dan MTsNegeri Model Brebes adalah bersifat konstruktif, bersifat membangun dan mengembangkan potensi serta kompertensi guru yang sudah ada, sehingga setelah dilakukan supervisi diharapkan guru dapat meningkatkan kompetensi yang dimilikinya dan memahami kekurangannya.

\section{Dampak Positif dan Pengaruh Supervisi Akademik dalam}

\section{Peningkatan Profesionalisme Guru}

Ada beberapa hal yang digaris bawahi yaitu sebagai berikut:

\section{Implementasi supervisi}

Implementasi supervisi akademik yang dilakukan dua kepala sekolah baik di SMP Al-Irsyad maupun di MTsN Model Brebes mengikuti prinsip-prinsip supervisi yang standar sebagaimana yang dilakukan di sekolah-sekolah sesuai dengan pedoman yang berlaku baik di bawah Kemenag maupun Kemendikbud. langkah-langkah dilakukan adalah meliputi perencanaan dan pelaksanaan supervisi. Pelaksanaannya lebih profesional dengan menggunakan berbagai teknik-teknik baik individu maupun kolektif 


\section{INTIQAD: JURNAL AGAMA DAN PENDIDIKAN ISLAM}

ISSN 1979-9950 (print) || ISSN 2598-0033 (online), http://jurnal.umsu.ac.id/index.php/intiqad

DOI: https://doi.org/10.30596/intiqad.v10i2.2492

Published December 2018

kolaboratif, langsung dan tidak pembelajaran. Beranjak dari hal ini, langsung.Hal ini untuk melihat kinerja guru sudah sejauh mana perkembangannya.

Hal ini sejalan dengan pendapat Sergiovanni (1987) yang menjelaskan bahwa refleksi praktis penilaian performa guru dalam supervisi akademik yaitu melihat kondisi yang menjawab berbagai pertanyaan, di antaranya: apa yang terjadi dalam pembelajaran di kelas? Apa yang dilaksanakan guru dalam pembelajaran di dalam kelas? Apa saja aktivitas yang bermakna bagi guru dan murid? Hal-hal apa saja yang dilakukan guru dalam mencapai tujuan pembelajaran? Apa saja kekurangan dan kelebihan guru dalam mengajar serta cara meningkatkan kualitas pembelajarannya? Dari pertanyaanpertanyaan tersebut akan mendeskripsikan kompetensi guru dalam proses pembelajaran.

Namun terdapat satu hal yang urgen dipertegas di sini bahwa setelah dilakukan evaluasi terhadap performa dalam kegiatan pembelajaran di dalam kelas, maka tugas guru belumlah selesai, melainkan harus ditindaklanjuti dengan membuat rancangan dan implementasi peningkatan kualitas dalam proses akademik, maka guru akan lebih mampu untuk membuat rancangan pembelajaran dalam memfaslitasi siswa dalam proses pembelajaran. Alfonso, Firth, dan Neville (1981) menegaskan bahwa suspervisi pembelajaran didefinisikan sebagai perilaku yang didesain secara ofisial oleh organisasi yang secara langsung berpengaruh pada perilaku guru untuk mampu memfasilitasi pembelajaran siswa dan mengarah pada tujuan organisasi. Beranjak dari definisi tersebut, terdapat beberapa inti pokok dalam supervisi akademik, yaitu:

a. Supervisi akademik yang dilakukan harus berpengaruh secara pada kompetensi guru dalam mengelola pembelajaran di dalam kelas.

b. Kegiatan supervisi akademik harus didesain secara teratur dan sistematis sehingga jelas waktu dimulainya program peningkatan kualitas pembelajaran serta waktu berakhirnya. Oleh karena itu, perlu adanya kerjasama supervisor dan guru dalam 


\section{INTIQAD: JURNAL AGAMA DAN PENDIDIKAN ISLAM}

ISSN 1979-9950 (print) || ISSN 2598-0033 (online), http://jurnal.umsu.ac.id/index.php/intiqad

DOI: https://doi.org/10.30596/intiqad.v10i2.2492

Published December 2018

mendesain program supervisi akademik.

c. Tujuan dari supervisi akademik yaitu membantu guru untuk memiliki kompetensi dalam memfasilitasi siswa dalam proses pembelajaran di dalam kelas.

Semua guru melaksanaan tugastugas di atas sebagai guru profesional dengan bimbingan dan binaan supervisor di situlah perlunya komunikasi yang dibangun di madrasah sehnggarasa asah, asih dan asuh berjalan secara kondusif. Sebagaimana keterangan kepala madrasah bahwa supervisi di MTsN sangat berpengaruh dalam peningkatan kinerja guru profesional sebagai berikut:

a. Guru termotivasi melengkapi perangkat pembelajaran

Semua guru memiliki RPP yang telah dipersiapkan sebelum masuk kelas karena telah ada pembinaan baik melalui MGMP maupun melalui guru inti yang ditunjuk oleh kepala madrasah.

b. Guru termotivasi meningkatkan komptensi diri dalam melaksanakan pembelajara secara profesional c. Tercapainya salah satu tujuan supevisi yaitu meingkakan kinerja dan kualitas guru yang lebih optimal.

d. Tercapainya tujuan supervisi yaitu menjadi guru yang profesional

\section{Peningkatan Profesionalisme Guru}

Dengan mempelajari data dan dokumen berikut hasil observasi di SMP Al-Irsyad Tegal bahwa terlihat peningkatan dari hasil supervisi tahun sebelumnya adalah berupa temuan sebagai berikut; kekurangan guru terletak pada proses pembelajaran pada kegiatan inti pada aspek eksplorasi, yaitu belum menggunakan metode pembelajaran yang variatif, sehingga siswa masih pasif, guru masih dominan berperan. Hal ini sesuai dengan pembatasan kajian yakni pada aspekaspek kompetensi profesional. Jika pada hasil supervisi tersebut aspek kompetensi profesional tadi masih kurang, maka pada tahun 2017 ini berdasarkan hasil observasi dan wawancara bisa terlihat pada aspekaspek kompetensi profesional sebagaimana dalam tabel, yaitu pada hasil supervisi tahun sebelumnya ada dua orang dari total 22 orang yang 


\section{INTIQAD: JURNAL AGAMA DAN PENDIDIKAN ISLAM}

ISSN 1979-9950 (print) || ISSN 2598-0033 (online), http://jurnal.umsu.ac.id/index.php/intiqad

DOI: https://doi.org/10.30596/intiqad.v10i2.2492

Published December 2018

dinilai masih kurang dalam hal kemampuan mengadakan variasi pembelajaran dalam kelas, penguasaan materi, dan kemampuan bertanya. Sedangkan pada hasil observasi, masingmasing kemampuan tersebut meningkat jumlahnya menjadi tiga orang dari total jumlah 20 orang yang diobservasi, dengan hasil Sangat Baik. Hasil ini terlihat hanya dari aspek kompetensi profesional guru. Dengan meningkatnya aspek kompetensi profesional guru tersebut, diharapkan guru akan lebih meningkatkan lagi aspek-aspek lainnya sehingga seluruh guru dapat tersertifikasi sebagai salah satu indikator guru profesional.

Untuk membandingkan lebih jauh presentase dan kategori pada nilai apa, harus diperdalam lagi dengan mengkaji aspek kompetensi pedagogik, kompetensi kepribadian, dan kompetensi sosial.

Sedangkan hasil observasi dan wawancara MTsN Brebes yang meliputi delapan (8) aspek mengalami peningkatan, meliputi; penguasaan materi, kemampuan membuka pelajaran, kemampuan bertanya, kemampuan melakukan variasi pembelajaran, menjelaskan materi, kemampuan mengelola kelas, kemampuan menutup pelajaran dan ketepatan waktu dan materi pembelajaran. Dengan meningkatnya aspek-aspek kompetensi tersebut, tentunya akan semakin meningkatkan mutu guru, yang pada akhirnya meningkat pula mutu peserta didik.

Berikut gambaran sistem pengaruh perilaku supervisi akademik :

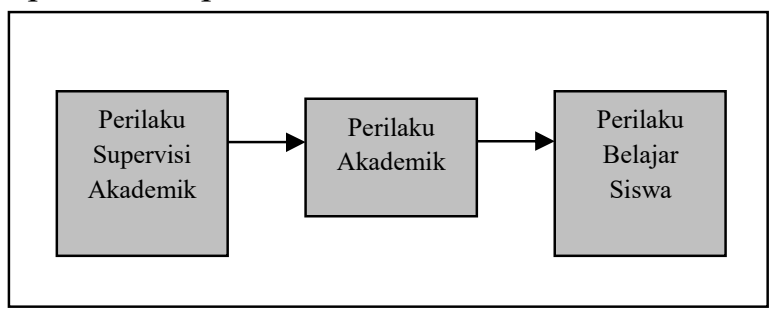

Sumber: Alfonso, RJ., Firth, G.R., \& Neville, R.F.1981. Instructional Supervision, A Behavior System, Boston: Allyn and Bacon, Inc., p. 45.

Gambar di atas memberikan deksripsi terkait dengan pengaruh pelaksaan supervisi akademik. Pelaksaan supervisi akademik akan memberikan pengaruh pada performa guru dalam melaksanakan proses pembelajaran. Dengan adanya bimbingan dan binaan yang diberikan supervisor maka akan membantu guru untuk meningkatkan kualitas dalam mengajar. Selanjutnya, dengan adanya peningkatan kualitas guru dalam mengelola pembelajaran maka akan berpengaruh pada pola 


\section{INTIQAD: JURNAL AGAMA DAN PENDIDIKAN ISLAM}

ISSN 1979-9950 (print) || ISSN 2598-0033 (online), http://jurnal.umsu.ac.id/index.php/intiqad

DOI: https://doi.org/10.30596/intiqad.v10i2.2492

Published December 2018

belajar siswa. Sehingga, goal (tujuan)

akhir dari pelaksanaan supervisi akademik adalah terbangunnya pola pembelajaran guru dan siswa secara optimal.

\section{Simpulan}

Berdasarkan data yang telah dikumpulkan dan dianalisis yang telah dilakukan mengenai implementasi supervisi akademik kepala sekolah sebagai upaya peningkatan profesionalisme guru di SMP Al-Irsyad Tegal dan MTsN Brebes Jawa Tengah maka dapat dirumuskan suatu kesimpulan:

1. Supervisi akademik merupakan suatu pengawasan yang dilakukan oleh seorang supervisor, dalam hal ini kepala sekolah SMP Al-Irsyad Tegal dan MTsN Brebes telah melaksanakan kegiatan supervisi agar kegiatan di sekolah dapat terarah untuk mencapai tujuan pendidikan yang diharapkan. Pelaksanaan supervisi akademik dilaksanakan secara sistematis oleh kepala sekolah dan bertujuan memberikan pembimbingan kepada para guru agar mampu melaksanakan perannya sebagai pendidik secara optimal. Supervisi akademik esensinya berkenaan dengan tugas pengawas untuk untuk membina guru dalam meningkatkan mutu pembelajarannya, sehingga pada akhirnya dapat meningkatkan prestasi belajar siswa. Kegiatan supervisi tersebut dilatarbelakangi oleh Peraturan Menteri Pendidikan Nasional No.13 Tahun 2007 mengenai kompetensi-kompetensi yang wajib dimiliki oleh kepala sekolah yang salah satunya adalah kompetensi supervisi.

2. Implementasi supervisi akademik yang dilakukan dua kepala sekolah baik di SMP Al-Irsyad maupun di MTsN Model Brebes mengikuti prinsip-prinsip supervisi yang standar sebagaimana yang dilakukan di sekolah-sekolah sesuai dengan pedoman yang berlaku baik di bawah Kemenag maupun Kemendikbud. Adapun langkahlangkah dilakukan adalah meliputi perencanaan dan pelaksanaan supervisi. Pelaksanaan supervisi pendidikan baik di SMP Al-Irsyad Tegal maupun di MTsNegeri Model Brebes tersebut dapat ditinjau dari beberapa hal, yaitu; tujuan supervisi, 


\section{INTIQAD: JURNAL AGAMA DAN PENDIDIKAN ISLAM}

ISSN 1979-9950 (print) || ISSN 2598-0033 (online), http://jurnal.umsu.ac.id/index.php/intiqad

DOI: https://doi.org/10.30596/intiqad.v10i2.2492

Published December 2018

fungsi supervisi, tipe serta teknik pelaksanaan supervisi yang digunakan.

3. Profesionalisme menjadi sebuah keharusan dalam sebuah pekerjaan, khususnya sebagai seorang pendidik. Guru sebagai seorang pendidik dituntut untuk menunjukkan profesionalitasnya dalam mengajar dalam menghadapi siswa dengan berbagai karakteristik dan modalitas belajar.

Pelaksanaan supervisi yang melibatkan kepala sekolah sebagai supervisor, guru senior yang dilibatkan sebagai supervisor, guru yang disupervisi, serta peserta didik mampu meningkatkan kinerja dan profesionalitas guru yang disupervisi serta mampu meningkatkan kualitas pembelajaran baik di SMP Al-Irsyad Tegal maupun di MTs Negeri Model Brebes. Hal ini terlihat dari beberapa indikator kompetensi profesionalitas guru yang dimiliki oleh mayoritas guru karena segala perangkat guru dalam melaksanakan tugasnya tersedia, kemudian dikembangkan oleh guru sesuai dengan bidang keahliannya masingmasing.

\section{Daftar Pustaka}

Arikunto, Suharsimi. (2004). Dasardasar Supervisi. Jakarta: Rineka Cipta.

Bungin, Burhan. (2007). Penelitian Kualitatif. Prenada Media Group: Jakarta.

Burton, WH, dan Lee J. Bruckner. (1995). Supervision. New York: Appleton Century-Craff, Inc.

Saudagar, Fachruddin dan Ali Idrus. (2011). Pengembangan

Profesionalitas Guru. cet. III, Jakarta: Gaung Persada Press.

Bafadal, Ibrahim. (2009). Peningkatan Profesionalisme Guru Sekolah Dasar: Dalam Kerangka Manajemen Peningkatan Mutu Berbasis Sekolah. Jakarta: Bumi Aksara.

Juwaini, Imam. (2016). Pelaksanaan Supervisi Akademik Kepala

Sekolah Dalam Peningkatan Kinerja Guru Pendidikan Agama Islam Di SMP Negeri 9 Surakarta. Tesis. 


\section{INTIQAD: JURNAL AGAMA DAN PENDIDIKAN ISLAM}

ISSN 1979-9950 (print) || ISSN 2598-0033 (online), http://jurnal.umsu.ac.id/index.php/intiqad

DOI: https://doi.org/10.30596/intiqad.v10i2.2492

Published December 2018

Iskandar. (2008). Metodologi Penelitian

Pendidikan dan Sosial: Kuantitatif

$\&$ Kualitatif, Gaung Persada Press.

Jerome Kirk \& Marc L. Miller. (1986).

Reliability and Validity in

Qualitatif Research. Sage

Publication California.

Moleong, Lexy J. (2005). Metodologi

Penelitian Kualitatif. edisi revisi,

Bandung: PT.Remaja Rosdakarya.

Mudlofir, Ali. (2012). Pendidik

Profesional. Jakarta: PT Raja

Grafindo Persada.

Mulyasa, E. (2011). Manajemen Dan

Kepemimpinan Kepala Sekolah.

Jakarta : PT Bumi Aksara.

Mulyasa, E. (2008). Menjadi Kepala

Sekolah Profesional. Bandung : PT

Remaja Rosdakarya.

Nurdin, Syafrudin. (2005). Guru

Profesional dan Implementasi

Kurikulum. Jakarta: PT Ciputat Press.

Purwanto, Ngalim. (2009). Administrasi dan Supervisi Pendidikan. Bandung: Remaja Rosdakarya.

Piet. A. Sahertian dan Frans Mataheru. (2000). Konsep Dasar dan Teknik: Supervisi Pendidikan (dalam Rangka Pengembangan Sumber
Daya Manusia). Jakarta: Rineka Cipta.

Pidarta, Made. (2009). Supervisi Pendidikan Kontekstual. Jakarta : Rineka Cipta.

Purwanto, Ngalim. (2010). Administrasi dan Supervisi Pendidikan. Bandung: PT Remaja Rosda Karya,

Prasojo, Lantip Diat dan Sudiyono. (2011). Supervisi Akademik. Yogyakarta: Penerbit Gava Media.

Sagala, Saeful. (2010). Supervisi Pembelajaran dalam Profesi Pendidikan. Bandung: Penerbit Alfabeta.

Saondi, Ondi dan Aris Suherman. (2012). Etika Profesi Keguruan. cet.ke-2, PT. Refika Aditama.

Saud, Udin S. dan Cicih Sutarsih. (2007). Pengembangan Profesi Guru SD. Bandung: UPI Press.

Subari. (1994). Supervisi Pendidikan Dalam Rangka Perbaikan Situasi Belajar Mengajar. Jakarta: Bumi Aksara.

Sudarwan, Danim dan Yunan Danim. (2010). Administrasi Sekolah dan Manajemen Kelas. Bandung: Pustaka Setia. 


\section{INTIQAD: JURNAL AGAMA DAN PENDIDIKAN ISLAM}

ISSN 1979-9950 (print) || ISSN 2598-0033 (online), http://jurnal.umsu.ac.id/index.php/intiqad

DOI: https://doi.org/10.30596/intiqad.v10i2.2492

Published December 2018

Sudjana, Nana. (2011) Supervisi

Akademik Membina

Suryanto dan Asep Jihad. (2013).

Profesionalisme Guru melalui

Supervisi Klinis. Jakarta: Binamita

Publishing.

Sugiyono. (2008). Metode Penelitian

Administrasi; Dilengkapi dengan

Metode R\&D. cet. V, Bandung:

Alfabeta.

Sugiyono. (2008). Metode Penelitian

Kuantitatif, Kualitatif dan R\&D.

cet.ke16, Bandung: Alfabeta.

Suralya dkk. Pelaksanaan Supervisi

Akademik Oleh Kepala Sekolah Menjadi Guru Profesional: Strategi Meningkatkan Kualifikasi dan Kualitas Guru di Era Global. Jakarta: Esensi Erlangga Group.

Suryosubroto. (2002). Proses belajar mengajar di sekolah. Jakarta: Rineka Cipta.

Sutopo. (2002). Metodologi Penelitian Kualitatif. Sebelas Maret University Press.

Usman, Moh. Uzer. (2002). Menjadi Guru Profesional. cet. XIV, Bandung: Remaja Rosdakarya.

Dalam Meningkatkan Kompetensi

Profesional Guru Pada SD Negeri

Lamura Kecamatan Simpang Tiga kabupaten Aceh Besar". Jurnal Administrasi Pendidikan.

Suryasubrata. (1997). Proses

BelajarMengajar di Sekolah.

Jakarta: RinekaCipta.

Suryadi, Ace. (2001). Menyoal Mutu

Profesi Guru. Kompas: Jakarta. 